\title{
INTELLIGENT AND DIGITAL TECHNOLOGIES IN THE CONSTRUCTION OBJECTS TECHNICAL DIAGNOSTICS
}

\author{
G.G. Kashevarova, A.E. Semina, S.V. Maksimova \\ Perm National Research Polytechnic Universities, Perm, RUSSIA
}

\begin{abstract}
The intelligent and digital technologies implementation into the civil engineer expert activities is able to provide alternative solutions to different qualifications specialists. This will increase the speed of data processing and the reliability of the expert opinion on the technical condition of the operated construction objects as well as will allow assessing their real residual resource for making a decision on the possibility of further exploitation. The ontology and the original technology for the main system components determination are necessary to achieve the goal (the confinement model) used for the structural and functional analysis of the knowledge system. The entire technologies set for the architectural and construction objects (digital documentation, scan results, thermal imager data, non-destructive survey methods data), data about structure's defects and damage, appropriate software as well as intelligent technologies (fuzzy logic, neural networks) are used for more thoroughly diagnose certain construction parts and transmit digital information to determine the technical condition category. Also, this data set can be used for following situations: a control of the dynamics of changes in the technical state of a construction object, an improvement the accuracy of determining the scope of repair work, an enhancement the quality of project documentation, methods for assessing the quality of restoration work and measures for the conservation of architectural monuments, etc.
\end{abstract}

Keywords: intelligent and digital technologies, ontology, confinement-model, architectural and construction objects, category of technical condition.

\section{ИНТЕЛЛЕКТУАЛЬНЫЕ И ЦИФРОВЫЕ ТЕХНОЛОГИИ В ТЕХНИЧЕСКОЙ ДИАГНОСТИКЕ ОБЪЕКТОВ СТРОИТЕЛЬСТВА}

\author{
Г.Г. Кашеварова, А.Е. Семина, С.В. Максимова \\ Пермский национальный исследовательский политехнический университет, г. Пермь, Россия
}

\begin{abstract}
Аннотация. Внедрение интеллектуальных и цифровых технологий в экспертную деятельность инженеров-строителей способно предоставлять альтернативные решения специалистам разной квалификации. Это повышает скорость обработки данных и достоверность экспертного заключения о техническом состоянии эксплуатируемых объектов строительства для принятия решения о возможности их дальнейшей эксплуатации, а также позволяет оценить их реальный остаточный ресурс. Для структурного и функционального анализа системы знаний использованы: онтологический анализ и оригинальная технология (конфайнментмоделирование) определения основных компонентов системы, необходимых для достижения цели - определения категории технического состояния строительного объекта. Для более тщательной диагностики отдельных деталей конструкций архитектурных и строительных объектов и передачи цифровой информации используется полный набор технологий (цифровая документация, результаты сканирования, данные тепловизора, данные методов неразрушающего контроля), данные о дефектах и повреждениях конструкции, соответствующее программное обеспечение, а также интеллектуальные технологии (нечеткая логика, нейронные сети). Также, этот набор данных может быть использован для: контроля динамики изменения технического состояния объекта строительства, повышения точности определения объема ремонтных работ, повышения качества проектной документации, способов оценки качества реставрационных работ и мероприятий по консервации памятников архитектуры и др.
\end{abstract}

Ключевые слова: интеллектуальные и цифровые технологии, онтология, конфайнмент-модель, архитектурностроительные объекты, категория технического состояния 


\section{INTRODUCTION}

Exploitation of any construction structure in accordance with the specific regulations demands technical diagnostics conduction. Often, conclusions of the technical examination are approved in the short time under uncertainty. Decisions are usually based on the opinions of the specialists considering their professional experience. Lack of sufficient knowledge leads to the erroneous conclusions and might be the cause of the premature failure of the construction object. Accordingly, there is growing attention to the development of intelligent expert systems in the complex field, such as diagnostics, inspection and monitoring of buildings structures. Such systems serve as a tool for information support for the development and decision-making processes. Deep knowledge in the field of construction and experience of an expert are required to address the problems of constructions survey, such as the complex nature of the building structures along with lack of regulatory documents connections, multiple, incomplete, inaccurate and contradictory results of an engineering object diagnostics, insufficient formulated assessment criteria, the problem of the "length of the technical conditions scale" (GOST (State Standard) scale, including 4 categories) and the blurring of the categories boundaries [1].

The intelligent and digital technologies introduction into the civil engineer expert activities provides the alternative solutions to the different qualifications specialists. The main task of the intelligent technologies is the knowledge processing related to solving complex issues in which logical (or semantic) information prevails over computational information [2, 3]. Taking the implementation into the process of technical condition diagnostic an additional technological level is advisable for this purpose. It should include the computer processing of the accumulated knowledge and practical experience. At the same time the knowledge embedded in a computer-oriented knowledge-base (KB) must be organized and formalized so that the user can quickly receive the necessary information. The structure of a comprehensive intelligent system for diagnostics of mass construction objects elaborated considering the current level of the computer technology development along with

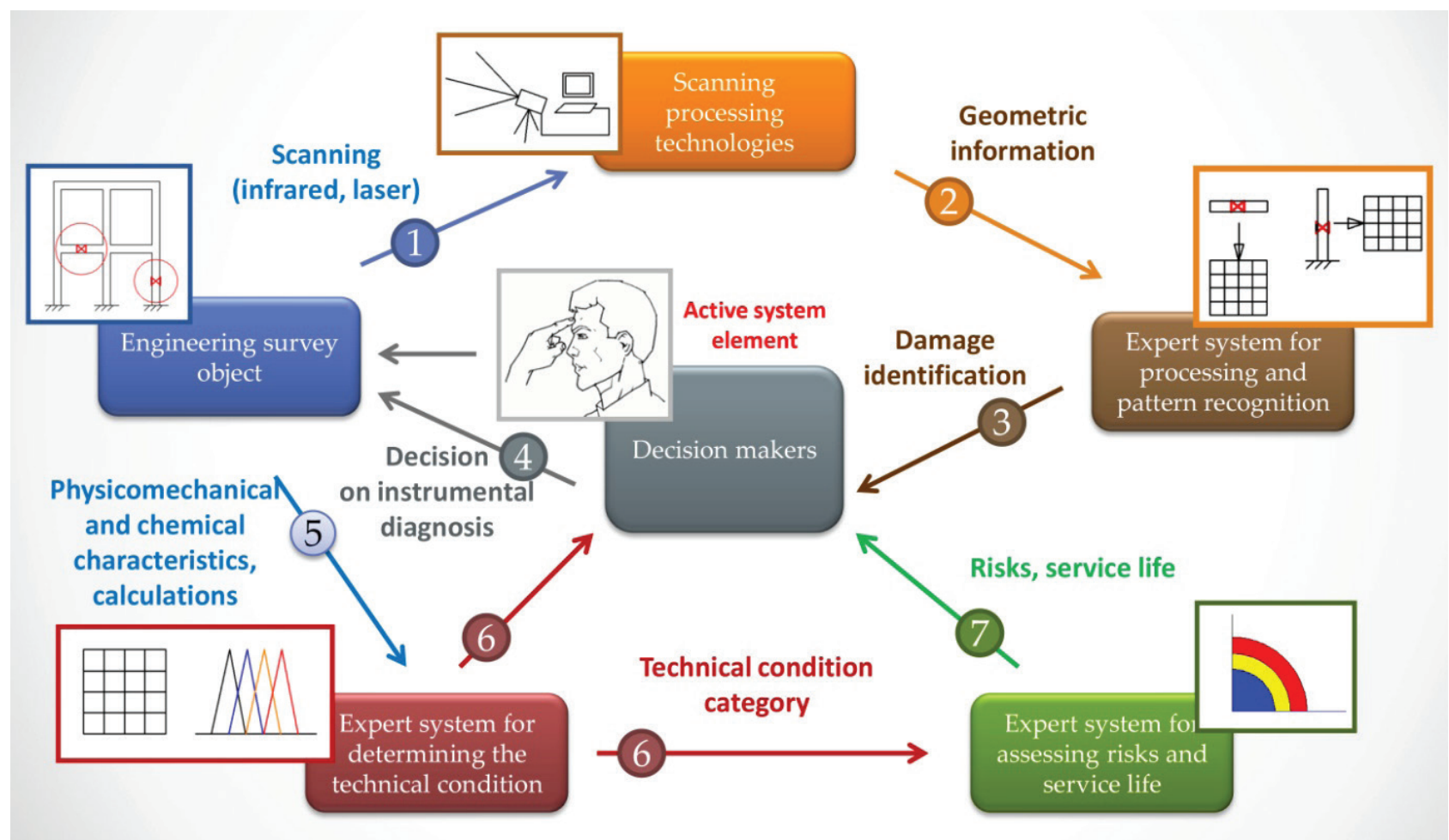

Figure 1. The structure of an integrated intelligent system for diagnostics of construction objects. 
evolution of the telemetry methods, digital and intelligent technologies. The developed structure consists of several expert systems (ES) which can operate separately or as a whole system (Fig. 1). Integration of the buildings technical condition diagnostics results into a holistic system mixed with the telemetry possibilities, laser scanning, intelligent and digital technologies, mathematical modeling enable to accelerate data processing and increase the reliability of the expert opinion about the technical condition of the exploited building constructions. Such system based on the identification of defects in load-bearing and enclosing structures as well as foundations and other constructions, also will allow evaluating the real residual constructions resource for decisions about the reconstruction, overhaul and destruction. An integrated approach to solving all these problems will allow obtaining a multiplier effect, while each included expert system expands due to the other system elements capabilities. In the near prospect the expert systems and neural network combination with the traditional programming technology will provide a revolutionary breakthrough in the applications integration of ready-made intelligently interacting modules. The current state of the expert systems and neural networks development in the construction sector can be characterized as a stage of the increasing interest as evidenced by the many publications of the authors: D.A. Pospelov, T.A.Gavrilova, V.F. Xoroshevskij, D. Rutkovskaya, E. Bernat, L. Gil, K. M. Hamdia, K. Van Balen, H. Li, S. Shtovba, A. Rotshtein, O. Pankevich, V.A. Sokolov, T.N. Soldatenko and others. In the technical diagnostics of the construction objects as well as in general construction sector, there are a lot of the national and international standards which must be taken into account since they form the basis for solving the ensuring safety problems of the construction facilities. This is a ready-made system model needs to be correctly represented in the formalized terminology to provide the user under certain structural rules which a computer can autonomously use in solving specific issues based on logical inference.

But at this stage, there is a certain gap between the technical development of general and detailed technical diagnostics building structures methods [4-7] and the intelligent systems methodology for organizing expert knowledge [8-14]. Consequently, there are the limitations in the possibilities of wider practical application of the intelligent systems in construction. The major difficulty is the interpretation of the entire volume of regulatory requirements into a machine-readable format.

In a certain sense the AI system simulates the intellectual activity of a person in general and the logic of the human reasoning in particular. Any intellectual person activity is inherently systemic. It involves the use of a set of the interrelated procedures on the way from setting a task and goals to finding and using solutions. And as the logic of the human expert reasoning in an intellectual system, machine processing should be easy to process; it should be structured, i.e. to represent the system of the subject area as a conceptual diagram. This requires: professional knowledge (theoretical and practical); understand the thinking process of a person - an experienced expert or a decisionmaker in a specific type of activity, highlighting the main steps of this process; use a readymade software tool that reproduces these actions.

\section{ONTOLOGICAL MODELS IN THE KNOWLEDGE SYSTEM STRUCTURAL AND FUNCTIONAL ANALYSIS}

Numerous models and knowledge representation methods have been proposed and tested with varying success for structuring information, such as: various logical models, semantic and neural networks, frames, production rules, etc. [13-18]. In recent years meaningful ontology works has been developed implementing new processing and presenting information methods at the junction of systems analysis, artificial intelligence and applied data analysis. Such works contain conceptual schemes for organizing the knowledge system of specific subject areas and ways of targeting this knowledge [19-22]. Ontology is widely used in all fields of natural language information processing. "Ontology" is a term in the artificial intelligence 
theory applied by specialists as one of the main formalisms of knowledge representation. It means formally presented knowledge in the form of anarray objects description as well as concepts and connections between them. In the simplest form the ontology composition is reduced to the basic concepts allocation for a specific subject area and the construction of links between themas the definition of relationships and interactions of basic concepts. An important feature of the ontological models in intelligent systems is that they are designed to be processed by agent software. All information needs to be presented in a formal form since a computer cannot understand the situation in the world as a person. For this purpose all concepts must be linked and patterns must be established, i.e. the expert's conclusions structure (frame) has to be identified. Domain ontology is usually built by domain experts or with their assistance. Meanwhile significant is not the concepts themselves as people's knowledge about these concepts and their exploitation by people. The logical and associative theories of thinking as two most popularapply as a basis forreconstruction an expert's reasoning. Traditional logic forms criteria that guarantee the accuracy, consistency of general concepts of reasoning and conclusions (classification, generalization, comparison, categorization, inference, abstraction, etc.). But a person rarely thinks in terms of mathematical logic. Thinking is a chain of ideas connected by general concepts. The main operations of such thinking are: associations acquired on the various connections basis, recalling past experiences, trial and error with random successes, etc. It all depends on the specific tasks, source material, and subject area complexity. Ontology allows restoring missing logical connections providing a systematic approach to the subject area study and makes inferences based on presented information. Ontological models are considered as knowledge bases of a special kind.

Any model is always a reality simplificationwith inherent fragmentation. In the process of identification of the various pieces of knowledge the main thing needs to be considered as follow: a basis for understanding processes and phenomena in relation with the development of knowledge about the subject area defines through the "center of the situation" as some holistic image, structure or important criterion. In meeting real challenges, the domain ontology can be constructed in various ways. It is important to know how to highlight the main lines.

\section{THE CONFINEMENT MODELLING TECHNOLOGY AS AN APPLIED TOOL FOR THE MAIN SYSTEM COMPONENTS DETERMINATION}

T.V. Gagin [23] proposed an original method for determination of the main system components which essential to achieve the stated objective and studying their influence on each other. This fundamentally stable model of the self-reproducing system developers called the Confinement ${ }^{\circledR}$ model. The "confinement" is the term taken from physics and literally means retention (confinement). The formation of ontology using confinement modelling is a system-cognitive analysis procedure. The domain model is represented in a sign oriented graph form with feedbacks (Fig. 2). Various events or key elements of the situation are located at the vertices of the graph. The arcs connecting the vertices represent the causal relationships between them. The essence of this approach lies in the presence of the fact that the system is closed in the form of a system loop, which contains the necessary and sufficient

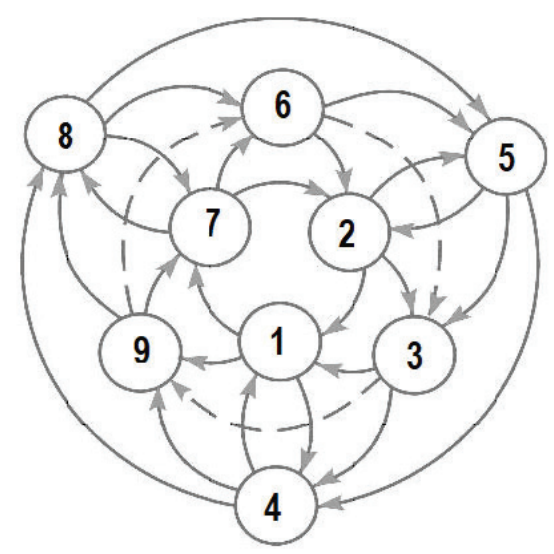

Figure 2. The confinement model. 
direct and reverse cause-and-effect relationships. The elements of the system loop are the focus of attention where to look and where to search. Meanwhile is considered that the result is generally known, and the model is focused on the strategy for achieving this result.

Recently this technology actively used in various sectors scientific developments [24, 25]. The confinement system allows seeing key points and important relationships as well as helps to highlight the most important and necessary information for solving a certain issue, i.e., makes it possible to take a systematic look at the process. Filling of the confinement model at the level of common sense (the numbers of the elements correspond to the order of their determination) allows discovering not only the elements necessary for understanding the system, but also their most important relationships: each element in its place should be logically linked to six others: three should call it, and three - to follow from it.

Accordingly, each element is both an effect and a cause. (1) is the goal and the result of the system. (2), (3) and (4) are the immediate causes of this result. At the same time the cause (2) in addition to the result itself should strengthen the cause (3) which enhances the cause (4). The element (4) itself must call the result and be strengthened by it. (5) is the element which have to simultaneously calls all three previous reasons. It is important that all three reasons. Reason (5) is related to (2). (6) is the reason for (2) and (5) at the same time. (7) has to call (6) and (2). (8) is the element interconnected with (7) and calls (6) and (5). (9) is the important element which should close the system and this is a serious test of our discourse. It is the cause for (7) and (8), being simultaneously a consequence of both cause (4) and the main result of system (1). The links indicated in the diagram (fig. 2) by the dotted line are described by the word "calls". In the finished diagram they have to close the middle circle: (3) - (9) - (6). The confinement model is clearly layered into three circles: inner, middle and outer. The inner and outer circles are practically equal. The central one is considered to be the manager and serves as a connecting link, transferring the influence from the inner circle to the outer one and vice versa.

There are three sectors within the model. They are marked with different colours: "R" - red, "G" - green, "B" - blue. Elements in the "R" sector (1) - (4) - (9) describe the "key results" and "specifics". These are the most "real" and obvious parts of the system. The "G" sector (6) - (7) - (8) is an incentive for the transformation of the specifics of the "R" sector into actions and the conclusions of the "B" sector (2) (3) - (5) which are the "procedural-thinking" sector covering the area of decisions, rules and conclusions. The logic of checks suggests the magical role of the element which is simultaneously located in the "control" central circle and the "transforming" G sector (the element (6) in the scheme). It often turns out to be significant and decisive.

\section{CASE OF THE CONFINEMENT MODELLING APPLICATION TO CONSTRUCT THE CONCEPTUAL MODEL STRUCTURE FOR DIAGNOSING THE BUILDINGS AND STRUCTURES TECHNICAL STATE}

Technical diagnostics of construction objects is carried out through a combination of mutually consistent and complementary practical, calculation, research and analytical procedures. Let's consider one example of the conceptual model forming process of an intelligent control system for the decision-making process on the buildings and structures technical condition (Fig. 3), using the technology of confinement modelling and a ready-made template [23].

The main criteria of damages type decisions and the requirement of the measures to bring the construction object to further safe exploitation is the technical condition category (CTC) of the building or structure (normative, operable, partially operable or emergency technical state). The technical condition category determinations of a construction object as a whole as the purpose of the construction expertise is the main component of the system (1). For this purpose the conduction 
of a survey of the building structures is necessary (8). It includes a large list of works consisting of various sections of building science.

Regular engineering inspections of the construction objects (6) should be carried out at least once every 10 years and at least once every 5 years for buildings operating in adverse condition in accordance with the requirements of the "Rules for the Inspection of Building Structures" and other regulatory documents. There may be scope for conduction extraordinary checks of the operational suitability of structures after emergency impacts (earthquakes, fire, explosive impacts, etc.) or upon detection of significant defects, damage and deformations during maintenance (7). The results of the building structures inspection make it possible to diagnose the technical condition of certain structures (5) and the construction object as a whole (1), i.e. carry out a set of surveys and necessary calculations to identify significant diagnostic parameters (2) and the defects and damage causes (3) used to judge the technical condition of the object. For this purpose, different methods of research and building elements examinations are applied as well as the survey the physical and mechanical properties of structures, foundations, soils (strength, deformation, physical and moral deterioration and other factors and parameters). This is necessary for a correct assessment and

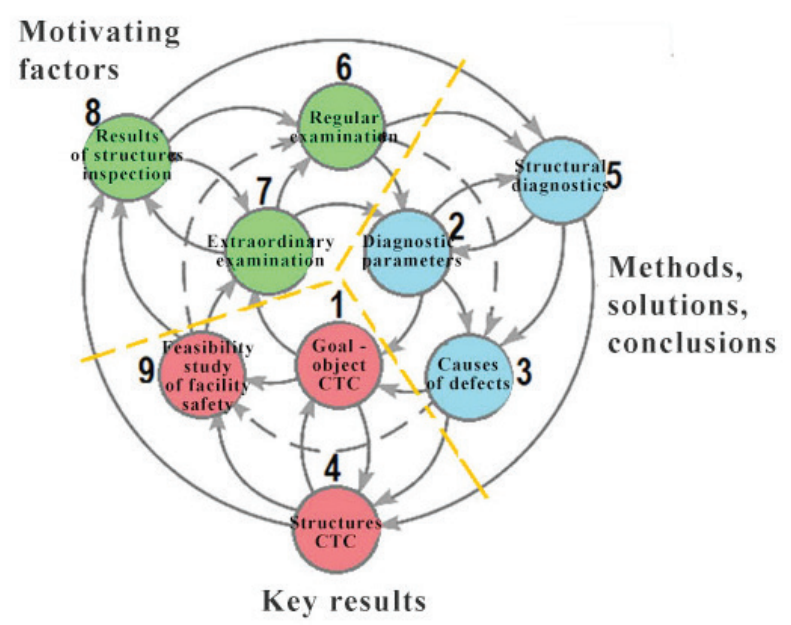

Figure 3. Ontograph of the definition of the CTC (the category of the technical condition) of a construction object. classification of the true state of structures (4) based on the results of examinations (8) and diagnostics (5). As a result, the risk should be assessed of destruction and residual resource if identified category of the technical state decrease for some structural elements. Such assessment is conducted for a feasibility study of the relevance of carrying out measures for the repair, reconstruction or demolition of the facility (9). Hence a conceptual confinement model of an intelligent system for diagnosing the technical condition of construction objects was formed. A specific system process operates within this system. It can be considered as a level 1 ontology that includes the required number of system processes.

Understanding the confinement model forming principles makes it possible next points: to unify the process of developing ontological knowledge bases and other subject areas, to facilitate lining of the structure in comparison with the known methods of constructing ontology [16, 20, 25], helps to filter out unimportant factors (which seemed important) and focus on those which are really affect the result.

At the same time, it should be understood that there is no single correct way to model the subject area. Always there are viable alternatives [6, 22]. Confinement modelling is an applied tool that allows facilitating the development of knowledge formalization models in intelligent systems, focusing on essentials further makes the right decisions by building action plans. Any element of this model can also be a sublevel. Creation of the sublevel structures both confinement models and other technologies and knowledge representation models can be used.

\section{DIGITAL TECHNOLOGIES FOR RECEIVING AND PROCESSING INFORMATION FOR ARCHITECTURAL AND CONSTRUCTION OBJECTS WITH THE TERRITORY REFERENCE}

Nowadays rapid digitalization of the architectural and construction industry is changing the technologies and possibilities of obtaining and 
processing information which is necessary for the construction objects diagnostics. Digital technologies are intensively implemented into the specialists' activities in the field of urban planning and architecture. Laser scanning, photogrammetry, and digital documentation methods make it possible to effectively collect three-dimensional and spatial data for architectural and construction objects into a database (DB) of point clouds [26, 27]. This is especially relevant for already existing and historical buildings or architectural complexes that can have defects and damage.

Parametric information models (BIM-models) are created [28] based on obtaining sufficiently accurate three-dimensional photogrammetric initial data for each building or structure after data processing. In figure 4 shows the results of such processing for a real architectural object St. Nicholas Church in Usolye of the Perm Krai as well as on figure 5 examples of the constructed BIM models in the cities of the Upper Kama region are presented.

Currently within the technical regulation framework is actively continuing implementation process of information modelling technologies at all stages of the life cycle of buildings and structures. This work carried out in creation the necessary regulatory and technical base process taking into account the needs of the construction process participants. Information models of each object are associated with the geographic information systems (GIS), i.e., with reference to the territory using an identification codes system assigned to each building (Fig. 6) [29].

Formalization and transformation into a machinereadable format and for the purpose of effective search, the obtained data is structured in the census form of the objects (Fig. 7).

The entire technologies set for architectural objects digital documentation not only in the form of three-dimensional point clouds, but also geospatial referenced data, as well as data about structures, defects and damage, provides researchers many options for subsequent work [30].

For instance, the historical and architectural heritage of Usolye database made it possible not only to

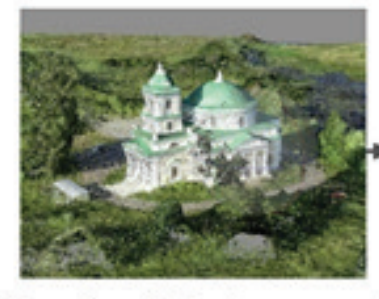

The colored photogrammetric , noint cloud

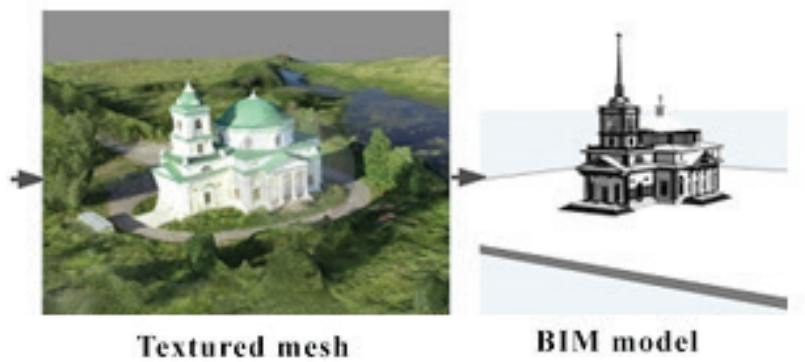

Figure 4. Photogrammetric data processing on the example of St. Nicholas Church in Usolye.

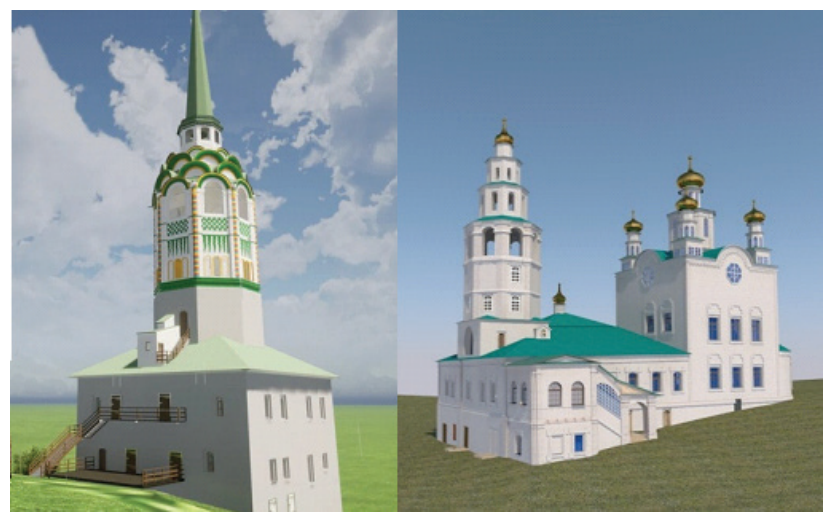

Figure 5. Examples BIM - models of churches and bell towers based on a point clouds and measured data in the cities of the Upper Kama region (Perm region).

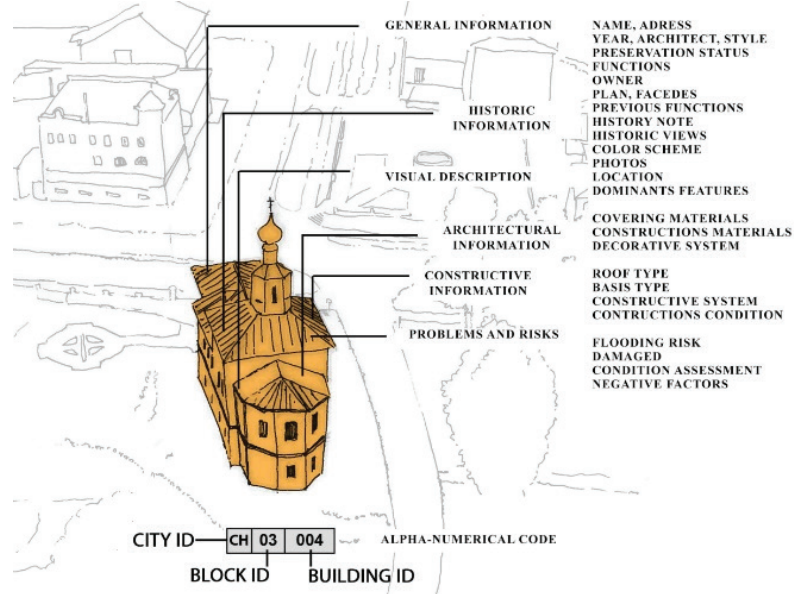

Figure 6. Information about an architectural object included in the database and object identifier 
visualize the entire historical and architectural environment in three-dimensional form but also to present cartographic analytical materials necessary for management decisions. The strategy for the Usolye Stroganovskoye territory development was elaborated on the basis of such three-dimensional and cartographic materials.

\section{CONCLUSION}

Using the scan results, thermal imager data, nondestructive survey methods data, appropriate software as well as intelligent (for example, neural network) technologies, it is possible to more thoroughly diagnose certain units and parts and transmit digital information to determine the category of technical condition designs. Also, this information can be used for following situations: to control the dynamics of changes in the technical state of a construction object, to improve the accuracy of determining the scope of repair work, improve the quality of project

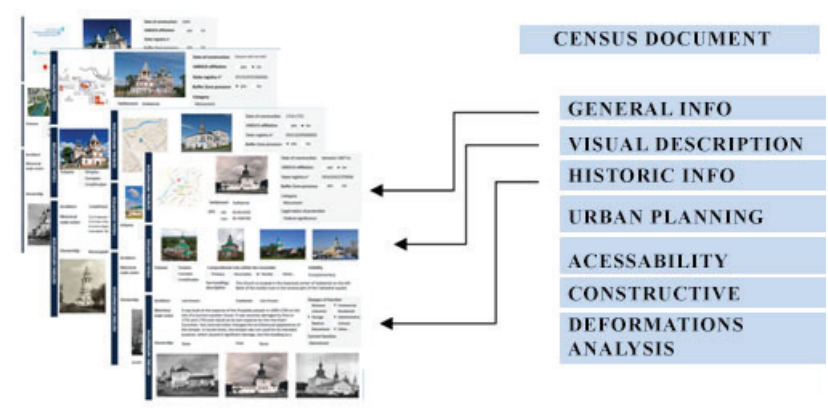

Figure 7. Census documents.

\begin{tabular}{|c||c|}
\hline DATA AQUISITION & \multicolumn{2}{|c|}{ PROCESSING } \\
\hline PHOTO & \multicolumn{2}{|c|}{$\begin{array}{l}\text { PANORAMAS } \\
\text { ANALYSIS }\end{array}$} \\
\hline AEROPHOTO & ORTHOPHOTO \\
\hline LANDSCAPE ANALYSIS & MAPPING \\
\hline CENSUS & ATTRIBUTIVE TABLES FOR MAPS \\
\hline LASER SCANNING & POINT CLOUDS PROCESSING \\
\hline & 3D MODELLING \\
\hline
\end{tabular}

Figure 8. Scheme of processing data on the historical and architectural environment and the result documentation, improve methods for assessing the quality of restoration work and measures for the conservation of architectural monuments, etc.

A well-structured database about the architectural and urban planning environment will allow not only effectively use existing information, but also add new information. In the presence of relevant and reliable input data, intelligent systems will be able to analyse not only the diagnostics of the technical condition and safety of construction objects, but also the urban planning situation.

The architecture represents a collection of not only numerical data, but also three-dimensional and semantic (ontology) data, which requires expert experience in data evaluation. Within architecture sector logical information often prevails over computational information and this can become a prospective field for intelligent systems.

Promotion of intelligent systems in relation to the functioning of each stage of the building "life cycle" will allow solving specific problems in the field of the architecture and constructions.

\section{ACKNOWLEDGEMENTS}

This project has received funding from the Ministry of Construction of the Russian Federation and the Russian Academy of Architecture and Construction Sciences in the field of construction sciences (Resolution of the Presidium of the RAACS dated 09.12.2020 No. 8).

\begin{tabular}{|l|l|l|}
\hline \multicolumn{1}{|c|}{ DATA TYPE } & \multicolumn{1}{c|}{ OUTPUT } \\
\hline GRAPHIC REPRESENTATION & VIEW CHARACTERISTICS \\
\hline POIN CLOUDS & 3D MODEL \\
\hline TEXTURE & GIS MODEL \\
\hline GIS LAYERS & POINT CLOUDS \\
\hline ATTRIBUTIVE TABLES GIS & 3D MODELS \\
\hline POINT CLOUDS \\
\hline 3D MODELS
\end{tabular}




\section{REFERENCES}

1. Classifier of the main types of defects in the construction and building materials industry 1993 (Moscow: Glavgosarhstrojnadzor Rossii) p. 95

2. Ed. Lapina A.V. Intelligent information systems http://files.lib.sfu-kras.ru/ebibl/ umkd/228/u_course.pdf (accessed: 27.11.2017)

3. S magin A.A., Lipatova S.V., Melnichenko A.S. Intelligent information systems2010(Ulyanovsk: UlGU) p 136

4. A guide to the practical identification of the suitability for the restoration of damaged building structures of buildings and structures and methods of their operational strengthening (Moscow:CNIIpromzdanij) 1996 p 98 .

5. Grozdov V.T. Signs of the emergency state of the load-bearing structures of buildings and structures (St. Petersburg: Izdatel'skij Dom $\mathrm{KN}+) 2000$ p 39

6. Guchkin I.S. Diagnostics of damages and restoration of operational qualities of structures(Moscow: Izdatel'stvo ASV) 2001. p. 171.

7. Boyko M.D. Diagnostics of damages and methods of restoration of operational qualities of buildings (St. Petersburg: Strojizdat) 1975. p. 336.

8. Zadeh, L. A. Fuzzy Logic, Neural Networks, and Soft Computing [Text] / L. A. Zadeh // Communications of the ACM. - 1994. - Vol. 37, № 3. - P. 77-84.

9. Ueno H., Ishizuka M. Representation and use of knowledge (Moscow:Mir) 1989 p 220

10. Kravchenko T.K. Modern information technologies in the development of computer decision support systemshttp:/www.mesi.ru/ ksit/k4sem24.zip(acessed: 09.04.2021)

11. Ruchkin V.N. Universal artificial intelligence and expert systems(St. Petersburg:BHVPeterburg) 2009, p. 240.

12. Gavrilova T.A., Khoroshevsky V.F. Knowledge bases of intelligent systems (St. Petersburg:Piter) 2000 p 384.
13. Rothstein A.P. Intelligent identification technologies: fuzzy logic, genetic algorithms, neural networks (Vinnytsia: UNIVERSUM)1999, p. 320.

14. Rutkovskaya，D. Nejronny`e seti, geneticheskie algoritmy`i nechetkie sistemy` / D. Rutkovskaya, M. Pilin`skij, L. Rutkovskij ; per. s pol`sk. I. D. Rudinskogo. - M. : Goryachaya liniya - Telekom, 2008. - 452 p.

15. Shtovba S., Rotshtein A., Pankevich O. Fuzzy rule based system for diagnosis of stone construction cracks of buildings Advances in Computational intelligence and learning, methods and applications 2002 (Dordrecht: Kluwer Academic Publisher) pp 401-412

16. Sokolov V.A. Building systems technical condition assessment based on the multilevel probabilistic analysis. Magazine of Civil Engineering. 20117 pp. 45-51

17. Soldatenko T.N. Model of identification and prediction of building design defects on the basis of its inspection results. Model of identification and prediction of building design defects on the basis of its inspection results. Magazine of Civil Engineering. 2011, 7, pp. 52-61.

18. Khader M. Hamdia. Expert System for Structural Evaluation of Reinforced Concrete Buildings in Gaza Strip Using Fuzzy Logic Thesis Submitted in Partial Fulfillment of the Requirement for the Degree of Master of Science in Civil Engineering Rehabilitation and Design of Structure 2010 p 92

19. Palagin A.V., Petrenko N.G., Malakhov K.S. Methodology for designing the ontology of the PDO Komp'yuterni zasobi, merezhi ta sistemi 2011, 10, pp. 5-12.

20. Nevzorova O.A. Ontolinguistic systems: methodological foundations of construction. Nauchnaya sessiya MIFI-2007. Sbornik nauchnyh trudov. Tom 3. Intellektual'nye sistemy i tekhnologii (Moscow), 2007, pp. 84-85.

21. Kleschev A.S., Artemyeva I.L. Relationships between domain ontologies, Part 1. Informacionnyj analiz, 2002, 1, pp. 4-9.

22. Kashevarova G.G., Tonkov Yu.L. Intelligent technologies in the inspection of building 
Intelligent and Digital Technologies in the Construction Objects Technical Diagnostics

structures. Academia. Architecture and Construction, 2018, 1, pp. 92-99.

23. Gagin T.V. How to highlight the main thing: the principles of confinement modelinghttp:// gagin.tv/index.php?page $=28 ; 2004$, http:// www.syntone.ru (acessed: 09.04.2021)

24. Popov D.V, Polyakovsky S.Yu., Mukhacheva N.N. Mathematical and software for confinement modeling of complex systems. Prinyatie reshenij v usloviyah neopredelennosti. Vypusk 4: Mezhvuzovskij nauchnyj sbornik (Ufa: Ufimsk.state aviation tech.un-t), 2007, pp. 19-26.

25. Mukhacheva N.N. Popov D.V.. Systemcognitive approach to the construction of ontological knowledge bases of information and intellectual resources. Vestnik RGRTU(Ryazan), 2009, 4, pp. 1-8.

26. Lezzerini M. Cultural Heritage Documentation and Conservation: Three-Dimensional (3D) Laser Scanning and Geographical Information System (GIS) Techniques for Thematic Mapping of Facade Stonework of St. Nicholas Church. International Journal of Architectural Heritage (Pisa, Italy) 201410(1) pp 9-19 DO I:10.1080/15583058.2014.924605

27. Miceli A., Morandotti M., Parrinello S. 3D survey and semantic analysis for the documentation of built heritage. The case study of Palazzo Centrale of Pavia University VITRUVIO - International Journal of Architectural Technology and Sustainability20205. p. 65. 10.4995/vitruvioijats.2020.13634

28. Parrinello S., Pontes A.G-B., Picchio F., Moreno C.R., López E.R. An integrated system for documentation, analysis and management of the architectural heritage: The general and the parts of the generalife palace EGA Revista de Expression Grafica Arquitectonica. 201924 pp 140-151 DOI : 10.4995/ega.2019.9527

29. Semina A.E., Maximova S.V. Digital census of Upper Kama towns architectural and urban environment IOP Conference Series: Materials Science and Engineering 2019 Vol. 6875 https://iopscience. iop.org/volume/1757899X/687 (acessed: 09.04.2021)

30. Maksimova S.V., Semina A.E. The analysis of causes of the 17-18 century architectural complex buildings destruction in Usolye, Russia Research in Building Engineering. EXCO20 : Investigando en Ingenieria de Edificacion EXCO20 (Valencia: Univ. Politecnica de Valencia, ETS de Ingenieria de Edificacion). 2020. pp. 109-117.

\section{СПИСОК ЛИТЕРАТУРЫ}

1. Классификатор основных видов дефектов в строительстве и промышленности строительных материалов [Текст]. - Введ. 1993-11-01. - М. : Главгосархстройнадзор России - 95 с.

2. Интеллектуальные информационные системы. Учебное пособие / кол. авторов под рук. Лапиной А. В. [Электронный ресурс]. - Режим доступа URL: http://files.lib.sfukras.ru/ebibl/umkd/228/u_course.pdf (дата обращения: 27.11.2017).

3. Смагин, А.А. Интеллектуальные информационные системы : учебное пособие / А. А. Смагин, С. В. Липатова, А. С. Мельниченко. - Ульяновск : УлГУ, 2010. - 136 с.

4. Пособие по практическому выявлению пригодности к восстановлению поврежденных строительных конструкций зданий и сооружений и способам их оперативного усиления [Текст].-М.: ЦНИИпромзданий, 1996.-98с.

5. Гроздов, В.Т. Признаки аварийного состояния несущих конструкций зданий и сооружений. СПб.: Издательский Дом $\mathrm{KN}+, 2000 .-39$ c.

6. Гучкин, И.С. Диагностика повреждений и восстановление эксплуатационных качеств конструкций. М.: Издательство АСВ, 2001. $171 \mathrm{c}$.

7. Бойко, М.Д. Диагностика повреждений и методы восстановления эксплуатационных качеств зданий [Текст] / М. Д. Бойко - Л. : Стройиздат, 1975. - 336 с. 
8. Zadeh, L.A. Fuzzy Logic, Neural Networks, and Soft Computing [Text] / L. A. Zadeh // Communications of the ACM. - 1994. - Vol. 37, № 3. - P. 77-84

9. Уэно Х., Исидзука М. Представление и использование знаний. М: Мир, 1989. - 220 с.

10. Кравченко, Т. К. Современные информационные технологии в развитии компьютерных систем поддержки принятия решений [Электронный ресурс] / Т. К. Кравченко, Н. Л. Наумова. - Режим доступа: http://www.mesi.ru/ksit/k4sem24.zip

11. Ручкин, В.Н. Универсальный искусственный интеллект и экспертные системы / В. Н. Ручкин, В. А. Фулин. - СПб. : БХВПетербург, 2009. - 240 с.

12. Гаврилова Т.А., Хорошевский В.Ф. Базы знаний интеллектуальных систем - СПб.: Питер, 2000. - 384 с.

13. Ротштейн, А.П. Интеллектуальные технологии идентификации: нечеткая логика, генетические алгоритмы, нейронные сети [Текст] / А. П. Ротштейн. - Винница: УНИВЕРСУМ - Винница, 1999. - 320 с.

14. Рутковская, Д. Нейронные сети, генетические алгоритмы и нечеткие системы / Д. Рутковская, М. Пилиньский, Л. Рутковский ; пер. с польск. И. Д. Рудинского. - М. : Горячая линия - Телеком, 2008. $452 \mathrm{c}$.

15. Shtovba S., Rotshtein A., Pankevich O. Fuzzy rule based system for diagnosis of stone construction cracks of buildings. // Advances in Computational intelligence and learning, methods and applications. Dordrecht: Kluwer Academic Publisher. 2002. Pp. 401-412.

16. Соколов, В.А. Оценка технического состояния строительных конструкций зданий на основе многоуровневого вероятностного анализа // Инженерно-строительный журнал. 2011. №7. С. 45-51

17. Солдатенко Т.Н. Модель идентификации и прогноза дефектов строительной конструкции на основе результатов ее обследования. // Инженерно-строительный журнал. 2011. № 7 (25). С. 52-61.
18. Khader M. Hamdia. Expert System for Structural Evaluation of Reinforced Concrete Buildings in Gaza Strip Using Fuzzy Logic. // A Thesis Submitted in Partial Fulfillment of the Requirement for the Degree of Master of Science in Civil Engineering Rehabilitation and Design of Structure. 2010. 92 p.

19. А.В. Палагин, Н.Г. Петренко, К.С. Малахов. Методика проектирования онтологии ПдО. // Комп'ютерні засоби, мережі та системи. 2011. № 10. С. 5-12.

20. Невзорова О.А. Онтолингвистические системы: методологические основы построения // Научная сессия МИФИ-2007. Сборник научных трудов. Том 3. Интеллектуальные системы и технологии. М., 2007. - C. 84-85.

21. Клещёв А.С., Артемьева И.Л. Отношения между онтологиями предметных областей. Ч.1. // Информационный анализ, Выпуск 1, C. 2, 2002. - C. 4-9.

22. Кашеварова Г.Г., Тонков Ю.Л. Интеллектуальные технологии в обследовании строительных конструкций // Academia. Архитектура и строительство. 2018. № 1. C. 92-99.

23. Гагин Т.В. Каквыделитьглавное:принципы Конфайнмент-моделирования / Т.В. Гагин, С.С. Бородина [Электронный ресурс]. Режим доступа: http://gagin.tv/index. php?page=28; 2004, http://www.syntone.ru.

24. Попов Д.В., Поляковский С.Ю., Мухачева Н.Н. Математическое и программное обеспечение конфайнмент-моделирования сложных систем // Принятие решений в условиях неопределенности. Выпуск 4: Межвузовский научный сборник. -Уфа: Уфимск. гос. авиац. техн. ун-т, 2007. - С. 19-26.

25. Н.Н. Мухачева, Д.В. Попов. Системнокогнитивный подход к построению онтологических баз знаний информационноинтеллектуальных ресурсов. Вестник РГРТУ. № 4 (выпуск 30). Рязань, 2009. C. 1-8. 
26. Lezzerini, M. Cultural Heritage Documentation and Conservation: ThreeDimensional (3D) Laser Scanning and Geographical Information System (GIS) Techniques for Thematic Mapping of Facade Stonework of St. Nicholas Church (Pisa, Italy) / M. Lezzerini, F. Antonelli, S. Columbu, R. Gadducci, A. Marradi, D. Miriello, A. Lazzeri // International Journal of Architectural Heritage, 2014. - vol. 10(1). - pp. 9-19. DO I:10.1080/15583058.2014.924605.

27. Miceli, Alessia \& Morandotti, Marco \& Parrinello, Sandro. (2020). 3D survey and semantic analysis for the documentation of built heritage. The case study of Palazzo Centrale of Pavia University. VITRUVIO - International Journal of Architectural Technology and Sustainability. 5. 65. 10.4995/ vitruvio-ijats.2020.13634.

28. Parrinello, S. An integrated system for documentation, analysis and management of the architectural heritage: The general and the parts of the generalife palace / S. Parrinello, A.G.-B Pontes, F. Picchio, C.R. Moreno, E.R. López // EGA Revista de Expression Grafica Arquitectonica, 2019. - vol. 24. - pp. 140-151. DOI : 10.4995/ega.2019.9527.

29. Digital census of Upper Kama towns architectural and urban environment / A.E. Semina, S.V. Maximova // IOP Conference Series: Materials Science and Engineering [Electronic resource]. - 2019. - Vol. 687, № 5. - Art. 055051. 7 p. Mode of access: https://iopscience. iop.org/ volume/1757-899X/687. - Title from screen. - DOI 10.1088/1757-899X/687/5/055051.

30. Анализ причин разрушения зданий историко-архитектурного комплекса 17-18 века в г. Усолье Пермского края / S.V. Maksimova, A.E. Semina//Research in Building Engineering. EXCO20 : Investigando en Ingenieria de Edificacion EXCO20 / Univ. Politecnica de Valencia, ETS de Ingenieria de Edificacion. Valencia : Reproexpres, 2020. - P. 109-117.
Galina G. Kashevarova, Corresponding Member of Russian Academy of Architecture and Construction Sciences, Professor, Dr.Sc., Head of department "Building constructions and computational mechanics”, Perm National Research Polytechnic University; Russia, 614010, Perm, ul. Kuibyshev, 109; phone +7 (342) 219-83-61, e-mail: ggkash@mail.ru.

Anastasia E. Semina, senior Lecturer of Department “Architecture and Urban Studies”, Perm National Research Polytechnic University; Russia, 614010, Perm, st. Kuibyshev, 109; Tel. +7 (342) 219-81-87, e-mail: semina. ae@yandex.ru.

Svetlana V. Maksimova, Advisor of the Russian Academy of Architecture and Construction Sciences, Dr.Sc.; Head of department “Architecture and Urban Studies”, Perm National Research Polytechnic University; Russia, 614010, Perm, st. Kuibyshev, 109; Tel. +7 (342) 219-81-87, e-mail: svetlana-maximova@yandex.ru.
Кашеварова Галина Геннадьевна, член-корреспондент PAАCH, доктор технических наук, профессор, заведующая кафедрой «Строительные конструкции и вычислительная механика» Пермского национального исследовательского политехнического университета; Россия 614010, г. Пермь, ул. Куйбышева, 109; тел. +7(342) 219-83-61, e-mail: ggkash@mail.ru.

Семина Анастасия Евгеньевна, старший преподаватель кафедры «Архитектура и урбанистика» Пермского национального исследовательского политехнического университета; Россия, 614010, г. Пермь, ул. Куйбышева, 109; тел. +7(342) 219-81-87, e-mail: semina.ae@yandex.ru.

Максимова Светлана Валентиновна, советник РААСН, доктор технических наук, заведующая кафедрой «Строительные конструкции и вычислительная механика» Пермского национального исследовательского политехнического университета; Россия 614010, г. Пермь, ул. Куйбышева, 109; тел. +7(342) 219-81-87, е-mail: svetlana-maximova@yandex.ru. 